\title{
Profile of Blood Transfusion Requests from Hospitals to Bandung Blood Transfusion Unit, Indonesian Red Cross in 2011
}

\author{
Syahla Nisaa Amalia, ${ }^{1}$ Nadjwa Zamalek $D,{ }^{2}$ Januarsih A. Rachman ${ }^{3}$ \\ ${ }^{1}$ Faculty of Medicine Universitas Padjadjaran, ${ }^{2}$ Department of Clinical Pathology Faculty of \\ Medicine, Universitas Padjadjaran/Dr. Hasan Sadikin General Hospital Bandung, ${ }^{3}$ Department of \\ Anatomy and Cell Biology Faculty of Medicine Universitas Padjadjaran Bandung
}

\begin{abstract}
Background: Blood transfusion as a part health services should be provided under appropriate indications and in a safe manner. In Indonesia, blood collection is run by the Blood Transfusion Unit of Indonesian Red Cross, where the blood is screened, processed into blood components, and finally distributed to hospitals. The purpose of this study was to describe the profile of blood transfusion requests from hospitals that do not have blood bank facility to the Bandung Blood Transfusion Unit, Indonesian Red Cross.

Methods: A descriptive study was carried out using secondary data from Bandung Blood Transfusion Unit Indonesian Red Cross (UTD PMI Bandung). All blood request forms from hospitals during 2011 were collected and analyzed. Variables in this study were the amount of blood units, blood components, blood type, and indications of blood transfusion.

Results: The number of blood units requested by hospitals were 35,841 units. The most blood units requested was in August 2011. The blood component requested was the packed red cell (61.1\%), whole blood (17.4\%), thrombocyte concentrate (10.6\%), and fresh frozen plasma (7\%). The total percentage of 0 , A, B and AB blood types were $36.1 \%, 28.6 \%, 27.5 \%$, and $7.9 \%$ respectively. The most frequent indication for transfusion was anemia (61.7\%), followed by surgery and other causes of bleeding.

Conclusions: The total blood units requested by hospitals vary each month. The most blood component requested is Packed Red Cell and the type of blood is 0 blood type. The most frequent indication is anemia. [AMJ.2015;2(3):433-39]
\end{abstract}

Keywords: Anemia, blood transfusion, blood type, packed red cell

\section{Introduction}

According to the World Health Organization (WHO), transfusion medicine is a part of a healthcare system that manages the supply and use of human blood. Transfusion is performed to replace lost blood from the body, which can be caused by trauma or the body has lost its ability to produce blood properly. ${ }^{1,2}$ Blood transfusion can give benefits to the recipients, but it can also carry risks or cause complications. Dangerous infections might be transmitted to the recipients if the transfusion was given without following the correct procedures. ${ }^{3}$ Blood transfusion has to be conductedaccording to the indication for each blood component. ${ }^{4,5}$ Blood components given to recipients are Whole Blood, Packed Red Cell, Washed Red Cell, Thrombocyte
Concentrate, Fresh Frozen Plasma, Liquid Plasma, Crypoprecipitate, and Buffy Coat. ${ }^{3,5}$

Before requesting blood to a Blood Transfusion Unit for transfusion purpose, a clinician should fill a blood request form. The form consists of information on patient's identity, indication for transfusion, type of blood component and its amount, blood transfusion time, and other related information which have to be submitted correctly and completely by the clinician. ${ }^{6}$ The next step is to take a blood sample from the patient. This blood sample will be used for compatibility testing to obtain the appropriate blood for optimum safety, efficiency of the transfusion, and to avoid destruction of the transfused blood. 5,6 One of the most important steps in compatibility testing is to determine the blood type of the patient. The blood type is determined based on the $\mathrm{ABO}$ and Rhesus

Correspondence: Syahla Nisaa Amalia, Faculty of Medicine, Universitas Padjadjaran, Jalan Raya Bandung-Sumedang Km.21, Jatinangor, Sumedang, Indonesia, Phone: +6287823392175 Email: syahla.nisaa_lima@yahoo.com 
Table 1 Number of Blood Requests per Month

\begin{tabular}{|c|c|c|}
\hline Month & Frequency (n) & Percentage (\%) \\
\hline January & 3,153 & 8.8 \\
\hline February & 2,802 & 7.8 \\
\hline March & 3,160 & 8.8 \\
\hline April & 2,800 & 7.8 \\
\hline May & 2,634 & 7.3 \\
\hline June & 2,977 & 8.3 \\
\hline July & 3,147 & 8.8 \\
\hline August & 3,261 & 9.1 \\
\hline September & 3,168 & 8.8 \\
\hline October & 2,879 & 8.0 \\
\hline November & 2,767 & 7.7 \\
\hline December & 3,093 & 8.6 \\
\hline Total & 35,841 & 100 \\
\hline
\end{tabular}

(Rh) blood types.4-6 In the ABO blood type system, there are four types of blood groups, which are: $A, B, A B$, and 0 . Different from the ABO blood type system, the Rhesus system consists only two types, Rhesus positive and negative. ${ }^{4,5}$

Data from the American Red Cross show that, in average, in every two seconds a person requires blood in the United States. This means that 4.5 million Americans need blood each year, ${ }^{7,8}$ In America, about $60 \%$ people are eligible to be blood donor, but only $5 \%$ of them become donors. ${ }^{9}$ In Indonesia, about 4.5 million blood units are needed, but only 3.5 million can be fullfilled. ${ }^{10}$

The Blood Transfusion Unit of the Indonesian Red Cross (Unit Transfusi Darah Palang Merah Indonesia, UTD PMI) is an organization that provides blood transfusion service in Indonesia. Blood transfusion service is provided by PMI, begins with mobilizing people to donate their blood, blood extraction, securing and storing the blood, processing blood into several components, as well as distributing them to the Hospital Blood Bank (Bank Darah Rumah Sakit, BDRS). The hospital will distribute these bloods to the recipients who need the blood or its component. Hospital Blood Bank is a working unit in a hospital, which assist in distributing blood transfusion to the recipients. The BDRS receives blood from the local Blood Transfusion Unit. The establishment of BDRS has to follow specific criteria; however, not all hospitals can meet the criteria to establish a BDRS. ${ }^{11}$
The purpose of this study was to describe the profile of blood requests to UTD PMI Bandung from hospitals without BDRS facility in the year 2011. This included the amount of total blood requested based on blood type, components, and its indication.

\section{Methods}

A descriptive study was carried out in UTD PMI Bandung. The study was performed using secondary data in blood request forms sent to the UTD PMI Bandung from hospitals without blood bank facility. The permission to conduct this study was given by UTD PMI Bandung before data collection began. All blood request forms from hospitals without blood bank facility to UTD PMI Bandung during 2011 were collected and analyzed.

Data from blood request forms were entered into computer and analyzed by using frequency distribution presented in either tables or figures. Observed variables in this study were number of blood units, blood type, type of blood components, and indication of blood transfusion. The indications for blood transfusion were grouped into several categories.

\section{Results}

The total number of blood request to the UTD PMI Bandung from hospitals without blood bank facility was 17,504, requesting 
Table 2 Number of Blood Requests Based on Blood Component

\begin{tabular}{lcc}
\hline \multicolumn{1}{c}{ Blood Component } & Frequency (n) & Percentage (\%) \\
\hline Whole Blood & 6,249 & 17.4 \\
Packed Red Cell & 21,916 & 61.1 \\
Washed Red Cell & 1,221 & 3.4 \\
Thrombocyte Concentrate & 3,782 & 10.6 \\
Fresh Frozen Plasma & 2,495 & 7 \\
Cryoprecipitate & 120 & 0.3 \\
Liquid Plasma & 53 & 0.1 \\
Buffy Coat & 5 & 0 \\
Total & 35,841 & 100 \\
\hline
\end{tabular}

35,841 blood units ( 2 units per patient). Only $7,872(45 \%)$ were completely filled and only $15,202(42.4 \%)$ blood unit requests included information on the indication.

Table 1 shows that the number of blood unit requested each month varies. Most requests were made in August. The average number of blood units requested per month was 2,987 blood units.

In table 2, the number of blood requested based on blood component in year 2011 is listed. Twenty one thousand nine hundred and sixteen (61.1\%) Packed Red Cell units were requested, followed by Whole Blood of 6,249 $(17.4 \%)$, Thrombocyte concentrate of 3,782 (10.6\%), Fresh Frozen Plasma of 2,495 (7\%), Washed Red Cells of 1,211 (3.4\%) blood units, Cryoprecipitate of 120 (0.3\%), Liquid Plasma of $53(0.1 \%)$, and Buffy Coat of $5(0 \%)$.

Figure 1 shows the percentage of each ABO blood type requested in the year of 2011. Figure 1 shows that the blood type most requested by hospitals without blood bank facility in 2011 was type 0 with a percentage of $36.1 \%$, followed by type $\mathrm{A}, \mathrm{B}$, and $\mathrm{AB}(28.6 \%$, $27.5 \%$, and $7.9 \%$ respectively).

The percentages of each indication can be seen in Table 3. Anemia was the highest indication followed by surgery. Table 3 shows the amount of blood requested based on indications and blood components by hospitals without blood bank facility. Some indications were grouped into several categories, such as other hematological disorder, other cause of bleeding, and others. For example, other hematological disorders are anaemia

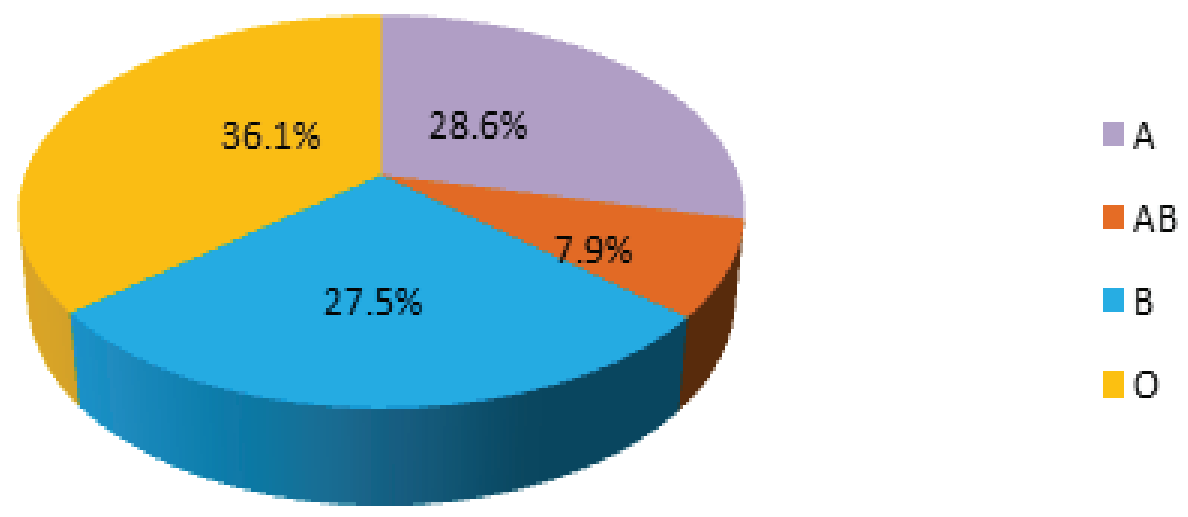

Figure 1 Percentage of Blood Requests Based on Blood Type 
Table 3 Number of Blood Request Based on Indication and Blood Component

\begin{tabular}{|c|c|c|c|c|c|c|c|c|c|c|}
\hline \multirow{2}{*}{ Indication } & \multicolumn{8}{|c|}{ Blood Component* } & \multirow[t]{2}{*}{ Total } & \multirow{2}{*}{$\begin{array}{c}\text { Percentage } \\
\text { (\%) }\end{array}$} \\
\hline & WB & PRC & WRC & TC & FFP & Cryo & LP & BC & & \\
\hline Anaemia & 968 & 7,472 & 330 & 291 & 309 & 10 & 5 & 0 & 9,385 & 61.7 \\
\hline Surgery & 1,008 & 1,259 & 2 & 16 & 225 & 0 & 0 & 0 & 2,510 & 16.5 \\
\hline $\begin{array}{l}\text { Other Cause of } \\
\text { Bleeding }\end{array}$ & 226 & 562 & 11 & 78 & 143 & 0 & 0 & 0 & 1,020 & 6.7 \\
\hline Caesarean Section & 667 & 171 & 0 & 3 & 2 & 0 & 0 & 0 & 843 & 5.5 \\
\hline Trombocytopenia & 8 & 41 & 2 & 642 & 111 & 0 & 0 & 0 & 804 & 5.2 \\
\hline $\begin{array}{l}\text { Other } \\
\text { Hematological } \\
\text { disorder }\end{array}$ & 12 & 70 & 1 & 44 & 27 & 0 & 0 & 1 & 155 & 1 \\
\hline Melena & 9 & 96 & 15 & 8 & 21 & 0 & 0 & 0 & 149 & 0.9 \\
\hline Kidney Disease & 1 & 72 & 4 & 0 & 0 & 0 & 0 & 0 & 77 & 0.5 \\
\hline Hypoalbuminemia & 0 & 0 & 1 & 0 & 60 & 0 & 2 & 0 & 63 & 0.4 \\
\hline Others & 16 & 38 & 4 & 4 & 10 & 0 & 0 & 0 & 72 & 0.4 \\
\hline Cancer & 6 & 21 & 1 & 3 & 0 & 0 & 0 & 0 & 31 & 0.2 \\
\hline $\begin{array}{l}\text { Intervention } \\
\text { Preparation }\end{array}$ & 12 & 27 & 0 & 0 & 4 & 0 & 0 & 0 & 43 & 0.2 \\
\hline Transfusion & 8 & 22 & 0 & 0 & 1 & 0 & 0 & 0 & 31 & 0.2 \\
\hline Childbirth & 17 & 2 & 0 & 0 & 0 & 0 & 0 & 0 & 19 & 0.1 \\
\hline Total & 2,958 & 9,853 & 371 & 1,089 & 913 & 10 & 7 & 1 & 15,202 & 100 \\
\hline
\end{tabular}

*WB = Whole Blood; PRC = Packed Red Cells; WRC = Washed Red Cells; TC = Thrombocyte Concentrate; FFP = Fresh Frozen Plasma; Cryo $=$ Cryoprecipitate Antihemophilic Factor; LP = Liquid Plasma; BC $=$ Buffy Coat

and thrombocytopenia, Disseminated Intravascular Coagulation, Hemophilia, Hereditary Pyropoikilocytosis, Idiopathic Thrombocytopenic Purpura, Leukemia and Thrombocytopenia, Myeloid Leukemia, Pancytopenia, low PCV, PPT, Thallassemia, and also prolonged bleeding. Other causes of bleeding indications are epistaxis, bloody cough, hematemesis, gum bleeding, intrapartum bleeding, vaginal bleeding, postpartum bleeding, placenta previa, and rupture. In addition, other indications are acidosis and hipoalbumin, common cold, malaria, general recovery, sepsis, septic arthritis, cirrhosis, and many unknown abbrevitation.

The result of this study presented in Table 3 shows the highest amount of blood component requested by hospitals was Packed Red cell, followed by Whole blood, Thrombocyte Concentrate and Fresh Frozen Plasma.. Indication for Whole Blood component was surgery (34.1\%), followed by anaemia (32.7\%). Packed Red Cell was the most requested blood component in almost all indications. The three highest indications for Packed Red Cell were anaemia (75.8\%), surgery $(12.7 \%)$, and other causes of bleeding (5.7\%). The three highest indications for Washed Red Cell were anaemia (88.9\%), melena (4\%), and other causes of bleeding (2.9\%). The three highest indications Thrombocyte Concentrate were thrombocytopenia (58.9\%), anaemia (26.7\%), and other causes of bleeding (7.1\%). The three highest indications for Fresh Frozen Plasma were anaemia (33.8\%), surgery (24.6\%), and other causes of bleeding (15.6\%).

Table 4 shows the number of each ABO blood type requested by hospitals without blood bank facility based on indications. Blood type 0 was the most requested by hospitals, followed by type B, A and AB.

\section{Discussion}

Packed Red Blood Cell is the most requested component in theyear 2011. This finding was in accordance with thetheory proposed by Kaplan and Skerrett that the most transfused blood component is the Packed Red Cell. ${ }^{12}$

The request for Whole Blood decreases, since requesting of specific blood component increases. ${ }^{13}$ Packed Red Cell is a blood component given to increase the oxygencarrying capacity or to speed up the delivery of 
Table 4 Number of Blood Request Based on Indication and Blood Type

\begin{tabular}{|c|c|c|c|c|c|c|}
\hline \multirow{2}{*}{ Indication } & \multicolumn{4}{|c|}{ Blood Type } & \multirow[t]{2}{*}{ Total } & \multirow{2}{*}{$\begin{array}{c}\text { Percentage } \\
\text { (\%) }\end{array}$} \\
\hline & A & B & $\mathrm{AB}$ & $\mathbf{0}$ & & \\
\hline Anaemia & 2,587 & 2,648 & 726 & 3,424 & 9385 & 61.7 \\
\hline Surgery & 656 & 808 & 199 & 847 & 2510 & 16.5 \\
\hline Other Cause of Bleeding & 336 & 280 & 73 & 331 & 1020 & 6.7 \\
\hline Caesarean Section & 257 & 201 & 87 & 298 & 843 & 5.5 \\
\hline Trombocytopenia & 234 & 303 & 53 & 214 & 804 & 5.2 \\
\hline Other Hematological Disorders & 29 & 49 & 11 & 66 & 155 & 1 \\
\hline Melena & 52 & 34 & 12 & 51 & 149 & 0.9 \\
\hline Kidney Disease & 14 & 34 & 3 & 26 & 77 & 0.5 \\
\hline Hypoalbuminemia & 25 & 4 & 6 & 28 & 63 & 0.4 \\
\hline Others & 10 & 19 & 14 & 29 & 72 & 0.4 \\
\hline Cancer & 8 & 2 & 0 & 21 & 31 & 0.2 \\
\hline Intervension Preparation & 9 & 10 & 9 & 15 & 43 & 0.2 \\
\hline Transfusion & 6 & 9 & 2 & 14 & 31 & 0.2 \\
\hline Childbirth & 5 & 5 & 1 & 8 & 19 & 0.1 \\
\hline Total & 4,228 & 4,406 & 1,196 & 5,372 & 15,202 & 100 \\
\hline
\end{tabular}

oxygen to the cells of the body. The condition with low oxygen-carrying capacity could be found such as in decreased bone marrow production, decreased life span of red blood cells, and chronic or acute hemorrhage (surgical or traumatic). Administration of Packed Red Cell does not only depend on the hemoglobin level, but also depends on the clinical symptoms and the status of hemodynamic. The hemoglobin level is not an absolute indicator for transfusion because the body has compensatory mechanism to adapt with low level of hemoglobin in the body. In that case, the transfusions are not necessary unless a sign of anemia is seen.,15-17 Packed Red Cell is often requested only based on anemic, without any information of the hemoglobin level or severity of anemia. ${ }^{15,16}$

Whole Blood can be given for active bleeding. In this case, the loss of red blood cells and decrease of blood volume can occur simultaneously, such as in surgery, childbirth, and caesarean section. 4 In all these conditions, there was no information regarding active bleeding. In addition, Table 3 shows that there was a demand for Whole Blood for thrombocytopenia. This situation is not in accordance with the theory. Thrombocyte blood components should be given for thrombocytopenia. ${ }^{4}$

Washed Red Cell is erythrocyte, which washed by using the sterile normal saline.
Theoretically, Washed Red Cell is to prevent an allergic reaction, such as in people with IgA deficiency were given transfusion of Packed Red Cell, due to the presence of plasma containing IgA..$^{15,16}$ A total of 371 Washed Red Cell was requested, most of them based on indication of anemia.

Thrombocyte concentrates are given to prevent or treat active bleeding associated with thrombocytopenia, however not all thrombocytopenia should be treated with thrombocyte concentrates. The administration of thrombocyte concentrate component depends on the clinical condition, the cause of thrombocytopenia, platelet count, and platelet function of patients. ${ }^{16}$ The indication of thrombocyte concentrate transfusion is in accordance with the indications of trombcytopenia, but the indication of thrombocytopenia was not clearly mentioned. Additionally, there were 251 units of thrombocyte concentrate requested for anemia.

Fresh frozen plasma consists of many proteins, including coagulation factors, albumin, and immunoglobulins. Furthermore, fresh frozen plasma administration is used to prevent or treat patients with active bleeding due to coagulation abnormalities caused by massive transfusion or liver disease, or prolonged prothrombin time and partial thromboplastine time.,5,12,18 Table 3 
shows that many fresh frozen plasma were used for anemia, but there was no further information regarding thecoagulation status. Cryoprecipitate is a blood component derived from Fresh Frozen Plasma, which contains factor VIII, von Willebrand factor, factor XIII, fibrinogen and fibronectin. Cryoprecipitate is usually used for patients with hemophilia A, von Willebrand (VWD) disease, and hypofibrinogenaemia related bleeding. ${ }^{3,5,19}$ Liquid plasma is the liquid component from Fresh Frozen Plasma stored in 24 hours to 5 days after thawed. ${ }^{15}$ Table 3 shows cryoprecipitate and liquid plasma were given to patients with anemia, but theoritically there is no indication for anemia.

Buffy coat is a concentrate of white blood cells and platelets obtained at the time centrifugation. Indications for Buffy Coat are infants with septic neutropenic and less neutrophil counts, and in infants with sepsis and bad neutrophil function.20 Due to limited data obtained, it was difficult to compare with the established theories.

Blood type 0 is the most requested with percentage as much as $36.1 \%$. Data from the American Red Cross shows that blood type $\mathrm{O}$ is the most requested by the clinicians. ${ }^{7}$ Most people in the world have blood type 0 , followed by type $\mathrm{A}, \mathrm{B}$, and $\mathrm{AB} .^{14}$

This study had limitations. From a total of 35,841 blood units requested, only $15,202(42.4 \%)$ blood units were known the indications. Therefore, the results of this study could not definitively prove why the blood was needed. There were many forms filled with several terminology with the same meaning.

Based on the results, itcan be concluded that the total blood units requested by hospitals varied each month, but the most requested was in August. The type of blood component most frequently requested is Packed Red Cell and 0 bloodtype. The three frequent indications are anemia, surgery and other causes of bleeding.

\section{References}

1. National Heart, Lung, and Blood Institute. What is a blood transfusion ?; 2012 [cited 19 April 2012]; Available from: http:// www.nhlbi.nih.gov/health/health-topics/ topics/bt/.

2. Natukunda B, Schonewille H, Sibinga CTS. Assessment of the clinical transfusion practice at a regional referral hospital in Uganda. Transfus Med. 2010;20(3):134-9.

3. Koh MBC, Lee YS, Chay J. Appropriate blood component usage. ISBT Science
Series. 2011;6(2):249-56.

4. WHO. The clinical use of blood: handbook. Geneva: WHO Library Cataloguing in Publication Data; 2002.

5. Hillyer CD, Shaz BH, Zimring JC, Abshire TC. Transfusion medicine and hemostasis: clinical and laboratory aspects. Oxford: Elsevier; 2009.

6. Roxby D. Current concepts in pretransfusion serological compatibility testing.ISBT ScienceSeries. 2011;6(2):2659.

7. American Red Cross. Blood facts and statistics [cited 2012 November 25]; Available from: http://www. redcrossblood.org/learn-about-blood/ blood-facts-and-statistics.

8. Health Watch Center. Blood facts and statistics (infographics); 2011 [cited 2013 February 9]; Available from: http://www. healthwatchcenter.com/2011/12/bloodfacts-and-statistics/

9. New York Blood Center. Blood statistics.; [cited 2012 December 2]; Available from: http://www.nybloodcenter.org/bloodstatistics.do?sid0 $=85 \&$ page_id=202.

10. Arriani A. Ayo, bersama berbagi kebaikan. Palang Merah Indonesia; 2012 [cited 2012 December 2]; Available from: http://www.pmi.or.id/ina/news/default. asp?act=detail \&p_id=847.

11. UTD PMI Pusat. Pedoman pelayanan transfusi darah. 3rd ed. Jakarta; 2007.

12. KaplanHS,SkerrettDL. Types of transfusion. Merck Manual Home Health Handbook; 2007 [cited 2012 May 1]. Available from: http://www.merckmanuals.com/home/ blood_disorders/blood_transfusion/ types_of_transfusions.html.

13. Cronan KM. Surgeries and procedures: blood transfusion. The Nemours Foundation; 2012 [cited 2012 November 25]; Available from: http://kidshealth. org/parent/system/surgery/blood_ transfusion.html\#.

14. O'Neil D. Distribution of blood types. Modern Human Variation:An Introduction to Contemporary Human Biological Diversity;1998-2012 [cited 25 November 2012] Available from: http://www.anthro. palomar.edu/vary/vary_3.htm.

15. Harmening DM. Modern blood banking \& transfusion practices. 5th ed. Melanie S. Kennedy M, Haifeng M. Wu M, editors. Philadelphia: F. A. Davis Company; 2005.

16. McCullough J. Transfusion medicine. 2nd ed. Philadelphia: Elsevier; 2005.

17. Liumbruno G, Bennardello F, Lattanzio A, 
Piccoli P, Rossetti G. Recommendations for the transfusion of red blood cells. Blood Transfusion. 2009;7(1):49-64.

18. Moiz B, Arif FM, Hashmi KZ. Appropriate and inappropriate use of fresh frozen plasma. J Pak Med Assoc. 2006;56(8):3569.

19. Droubatchevskaia N, Wong MP, Chipperfield KM, Wadsworth LD, Ferguson
DJ. Guidelines for cryoprecipitate transfusion. BCMJ. 2007;49(8):441-5.

20. Charge Nurse - Newborn. Buffy Coat Concentrate. Newborn services clinical guideline;2003 [cited 2012 December 2] Available from: http://adhb.govt. nz / n ewborn / guidelines / blood / bloodproducts/buffycoat.htm. 